\title{
PENGEMBANGAN PERANGKAT PEMBELAJARAN IPA MODEL INKUIRI TERBIMBING DITUNJANG MEDIA PhET UNTUK MENINGKATKAN KETERAMPILAN PROSES SAINS SISWA
}

\author{
Yunita $^{\text {1) }}$ Sri Poedjiastoeti ${ }^{2)}$ Rudiana Agustini $^{3)}$ \\ ${ }^{1)}$ Mahasiswa Program Studi S2 Pendidikan Sains, Universitas Negeri Surabaya \\ ${ }^{2)}$ Dosen Program Studi S2 Pendidikan Sains, Universitas Negeri Surabaya \\ ${ }^{3)}$ Dosen Program Studi S2 Pendidikan Sains, Universitas Negeri Surabaya \\ Email: nitha.hasan@yahoo.com ${ }^{1)}$
}

\begin{abstract}
Abstrak: Penelitian ini bertujuan untuk menghasilkan perangkat pembelajaran IPA model inkuiri terbimbing ditunjang media PhET yang layak digunakan untuk meningkatkan keterampilan proses sains siswa SMP. Model pengembangan perangkat yang digunakan adalah model Research \& Development R\&D yang meliputi sepuluh langkah yang berkesinambungan. Perangkat pembelajaran yang telah dikembangkan divalidasi oleh pakar serta diuji coba II pada 30 siswa kelas VII SMP tahun ajaran 2016/2017 dengan rancangan One-Group Pre test and Post test Design. Temuan penelitian ini sebagai berikut: 1) validitas perangkat pembelajaran yang dikembangkan dengan kategori sangat valid, 2) keterlaksanaan RPP berkategori sangat baik dengan persentase reliabelitas 98\%, 3) aktivitas siswa tertinggi pada aktivitas melakukan percobaan dan mengerjakan LKS, 4) respon siswa terhadap perangkat dan pelaksanaan pembelajaran mencapai persentase di atas $80 \%$ dengan kriteria sangat kuat; dan 5) Peningkatan keterampilan proses sains dengan N-gain 0,80, kriteria tinggi, Disimpulkan bahwa perangkat pembelajaran IPA model inkuiri terbimbing ditunjang media PhET yang dikembangkan telah layak untuk meningkatkan keterampilan proses sains siswa SMP.
\end{abstract}

Kata Kunci: Pembelajaran IPA, inkuiri terbimbing, PhET, Keterampilan Proses Sains.

\begin{abstract}
The purpose of this research is to produce learning materials of science bases on guided inquiry model intgrated with PhET media valid to excercise science process skills of Junior High School Student. The learning materials development model used is Research \& Development (R\&D) with ten steps are related. Learning materials that developed was validated by experts and try out II toward 30 students of VII grade students on academic year 2016/2017 by using One Group Pre-test and Post Test Design. The results of this research : 1) The validity of the materials is very valid category; 2) the realization of the lesson plan categorized very good with percentage $98 \%$, students response towards the learning material, 3) student activities highest in the activity of doing experiments and perform tasks LKS, 4) implementation learning reaches over $80 \%$ categorized as very strong; and 5) the increase in science process skills with $\mathrm{N}$-gain 0.80 , high criteria. It was concluded that learning material of science bases on guided inquiry model intgrated with PhET media that developed is eligible for increasing Junior High School students science process skills.
\end{abstract}

Keyword: Science learning, Guided inquiry model, PhET, science process skills. 


\section{PENDAHULUAN}

Pembelajaran yang dikehendaki kurikulum 2013 adalah pembelajaran yang berpusat pada siswa (student centered active learning) dengan pendekatan saintifik. Pendekatan saintifik merupakan pendekatan yang dalam kegiatan intinya mencakup komponen mengamati, menanya, mencoba, mengolah, mengkomunikasikan (pola $5 \mathrm{M}$ ). Pendekatan saintifik selain dapat menjadikan siswa lebih aktif dalam mengkonstruksi pengetahuan dan keterampilannya, juga dapat mendorong siswa untuk melakukan penyelidikan guna menemukan fakta-fakta dari suatu fenomena atau kejadian.

Pendidikan IPA di SMP/MTs berdasarkan kurikulum 2013 menekankan adanya kegiatan inkuiri ilmiah (scientific inquiry), sehingga siswa dapat belajar berinteraksi dengan benda-benda di alam secara alamiah. Siswa melakukan proses ilmiah secara alamiah, seperti mengamati, mendeskripsikan, mengklasifikasikan, mengukur, melakukan percobaan, menganalisis data, dan menyimpulkan. Senada dengan hal ini National Science Education Standards (1996) menyatakan bahwa pembelajaran IPA merupakan sesuatu yang harus dilakukan oleh siswa bukan sesuatu yang dilakukan terhadap siswa. Artinya dalam pembelajaran IPA, siswa dituntut untuk belajar aktif yang terimplikasikan dalam kegiatan secara fisik dan mental.

Kimia sebagai salah satu aspek dalam pembelajaran IPA SMP, dalam konteks pencapaian kompetensi siswa menekankan pada pemberian pengalaman langsung untuk mengembangkan kompetensi agar siswa mampu menjelajahi dan memahami alam sekitar secara ilmiah. Materi kimia sebagian besar dapat dikaitkan dan diaplikasikan dengan fenomena yang ada dalam kehidupan sehari-hari, salah satunya yaitu asam, basa, dan garam. Materi asam, basa, dan garam merupakan bagian dari kimia yang terdapat pada Kurikulum 2013 SMP/MTs pada semester ganjil kelas VII. Materi asam, basa, dan garam terdiri dari sub materi sifat asam, basa, dan garam, skala keasaman, dan indikator asam basa. Kompetensi dasar yang harus dikuasai siswa diantaranya adalah melakukan penyelidikan untuk menentukan sifat larutan yang ada di lingkungan sekitar menggunakan indikator buatan maupun alami. Sehingga dalam proses pembelajaran IPA siswa tidak hanya dituntut untuk menghafal namun juga diharapkan mampu memecahkan masalah IPA dalam kehidupan sehari-hari. Sehubungan dengan permasalahan tersebut, maka diperlukan suatu model pembelajaran yang dapat melatihkan keterampilan proses sains dan melibatkan siswa secara langsung dalam memperoleh materi.

Model pembelajaran yang melibatkan siswa pada pengalaman belajar secara langsung adalah menggunakan model pembelajaran inkuiri (inquiry learning). Gulo (2002) menyatakan bahwa model pembelajaran inkuiri sebagai suatu rangkaian kegiatan belajar yang melibatkan secara maksimal seluruh kemampuan siswa untuk mencari dan menyelidiki secara sistimatis dan analitis, sehingga mereka dapat merumuskan sendiri penemuannya dengan percaya diri. Berdasarkan hasil wawancara informal dengan guru IPA kelas VII di SMP Widya Darma Surabaya, menunjukkan bahwa pembelajaran IPA khususnya kimia kurang memberikan kesempatan kepada siswa untuk mengembangkan keterampilan proses sains melalui aktifitas eksperimen, hal ini disebabkan karena belum tersedianya LKS untuk melatihkan keterampilan proses sains siswa dan sekolah yang tidak dapat melaksanakan praktikum disebabkan oleh berbagai kendala. Mulai dari tidak tersedianya laboratorium, kurangnya peralatan, hingga mahalnya zat-zat kimia bahan praktek, sehingga dalam kondisi seperti ini guru dituntut memiliki alternatif pembelajaran agar tetap dapat melatihkan keterampilan proses sains melalui kegiatan eksperimen, salah satunya dengan menggunakan media.

Berdasarkan uraian latar belakang di atas, maka dalam upaya mengembangkan perangkat pembelajaran yang dapat meningkatkan keterampilan proses sains siswa dalam pembelajaran IPA khususnya kimia, peneliti tertarik untuk melakukan penelitian yang berjudul "Pengembangan Perangkat Pembelajaran IPA Model Inkuiri Terbimbing Ditunjang Media PhET untuk Meningkatkan Keterampilan Proses Sains Siswa". Tujuan utama dari penelitian ini adalah tersedianya perangkat pembelajaran IPA dengan model inkuiri terbimbing yang layak untuk meningkatkan keterampilan proses sains siswa ditunjang media PhET.

\section{METODEPENELITIAN}

Penelitian ini adalah penelitian pengembangan (developmental research) yang mengacu pada metode penelitian Research and Developmental (R\&D) oleh Sugiyono (2014). Penelitian ini mengembangkan perangkat pembelajaran IPA model inkuiri terbimbing ditunjang media PhET untuk meningkatkan keterampilan proses sains siswa. Perangkat pembelajaran IPA yang dihasilkan meliputi rencana pelaksanaan pembelajaran (RPP), Lembar Kegiatan Siswa (LKS), dan Tes Keterampilan Proses Sains.

Subjek uji coba II pada penelitian ini adalah siswa kelas VII SMP Widya Darma Surabaya. Tahap uji coba II dilaksanakan pada kelas VIIa sebanyak 30 siswa. Penelitian ini dilaksanakan di SMP Widya Darma Surabaya, pada semester genap tahun ajaran 2016/2017 di kelas VII. Pengambilan data penelitian ini dilaksanakan pada bulan Januari 2017.

\section{HASIL DAN PEMBAHASAN}

\section{A. Hasil Validasi Perangkat Pembelajaran}

\section{Validasi RPP}

Tabel 4.1 Hasil validasi rencana pelaksanaan pembelajaran (RPP)

\begin{tabular}{|l|l|c|c|l|}
\hline $\mathbf{N}$ & Aspek yang dinilai & $\begin{array}{c}\text { Rer } \\
\text { ata } \\
\text { Sko }\end{array}$ & $\begin{array}{c}\text { Ser } \\
\text { r }\end{array}$ & $\begin{array}{l}\text { ata } \\
(\%)\end{array}$ \\
\hline
\end{tabular}




\begin{tabular}{|c|c|c|c|c|}
\hline $\begin{array}{l}\mathbf{N} \\
\mathbf{0 .}\end{array}$ & Aspek yang dinilai & $\begin{array}{c}\text { Rer } \\
\text { ata } \\
\text { Sko } \\
\text { r }\end{array}$ & $\mathbf{K}$ & $\begin{array}{l}\text { Rer } \\
\text { ata } \\
(\%)\end{array}$ \\
\hline \multirow{6}{*}{ I. } & \multicolumn{4}{|l|}{ FORMAT } \\
\hline & $\begin{array}{ll}1 . & \begin{array}{l}\text { Kelengkapan } \\
\text { rumusan identitas }\end{array}\end{array}$ & 4 & SV & 100 \\
\hline & $\begin{array}{ll}\text { 2. } & \begin{array}{l}\text { Pembagian materi } \\
\text { sesuai alokasi waktu }\end{array}\end{array}$ & 4 & SV & 100 \\
\hline & 3. Sistem penomoran & 4 & SV & 100 \\
\hline & $\begin{array}{ll}\text { 4. } & \text { Pengaturan } \\
& \text { ruang/tata letak }\end{array}$ & 4 & SV & 100 \\
\hline & $\begin{array}{lll}5 . & \text { Jenis dan } & \text { ukuran } \\
\text { huruf sesuai } & \end{array}$ & 4 & SV & 100 \\
\hline \multirow{13}{*}{ II. } & \multicolumn{4}{|l|}{ ISI } \\
\hline & $\begin{array}{ll}\text { 1. } & \text { Menuliskan } \\
& \text { Kompetensi Inti }\end{array}$ & 4 & SV & 100 \\
\hline & $\begin{array}{ll}\text { 2. } & \text { Menuliskan } \\
& \text { Kompetensi Dasar }\end{array}$ & 4 & SV & 100 \\
\hline & Indikator & 3.5 & SV & 87.5 \\
\hline & $\begin{array}{ll}4 . & \begin{array}{l}\text { Menuliskan tujuan } \\
\text { pembelajaran }\end{array} \\
\end{array}$ & 3.5 & SV & 87.5 \\
\hline & $\begin{array}{ll}5 . & \text { Ketepatan } \\
& \text { penjabaran KD ke } \\
& \text { dalam indikator } \\
\end{array}$ & 3 & SV & 75 \\
\hline & $\begin{array}{ll}6 . & \text { Ketepatan } \\
& \text { penjabaran tujuan } \\
& \text { pembelajaran dari } \\
& \text { indikator. } \\
\end{array}$ & 3.5 & SV & 87.5 \\
\hline & $\begin{array}{ll}7 . & \text { Mengembangkan } \\
\text { tujuan } \\
\text { pembelajaran untuk } \\
\text { melatihkan } \\
\text { keterampilan proses } \\
\text { sains siswa. } \\
\end{array}$ & 3.5 & SV & 87.5 \\
\hline & $\begin{array}{l}\text { 8. Pemilihan strategi, } \\
\text { metode dan sarana } \\
\text { pembelajaran } \\
\text { dilakukan dengan } \\
\text { tepat. }\end{array}$ & 3.5 & SV & 87.5 \\
\hline & $\begin{array}{ll}9 . & \begin{array}{l}\text { Kesesuain dengan } \\
\text { urutan materi. }\end{array} \\
\end{array}$ & 3.5 & SV & 87.5 \\
\hline & $\begin{array}{ll}10 . & \text { Kesesuaian dengan } \\
& \text { sintaks model } \\
& \text { inkuiri terbimbing } \\
\end{array}$ & 3.5 & SV & 87.5 \\
\hline & $\begin{array}{ll}\text { 11. } & \text { Kegiatan guru dan } \\
& \text { kegiatan siswa } \\
& \text { dirumuskan secara } \\
& \text { jelas dan } \\
& \text { operasional. } \\
\end{array}$ & 3,5 & SV & 87.5 \\
\hline & $\begin{array}{ll}12 & \text { Terdapat } \\
\text { komponen dalam } \\
\text { skenario RPP yang } \\
\text { melatihkan } \\
\text { keterampilan } \\
\text { proses sains siswa. }\end{array}$ & 3.5 & SV & 87.5 \\
\hline
\end{tabular}

Pengembangan Perangkat Pembelajaran IPA Model Inkuiri Terbimbing...........

\begin{tabular}{|c|c|c|c|c|}
\hline $\begin{array}{l}\text { N } \\
\text { o. }\end{array}$ & Aspek yang dinilai & $\begin{array}{c}\text { Rer } \\
\text { ata } \\
\text { Sko } \\
\text { r }\end{array}$ & $\mathbf{K}$ & $\begin{array}{l}\text { Rer } \\
\text { ata } \\
(\%)\end{array}$ \\
\hline \multirow{5}{*}{ II } & 13. $\begin{array}{l}\text { Kelayakan sebagai } \\
\text { perangkat } \\
\text { pembelajaran IPA } \\
\text { berbasis inkuiri } \\
\text { terbimbing. }\end{array}$ & 3.5 & SV & 87.5 \\
\hline & \multicolumn{4}{|l|}{ BAHASA } \\
\hline & $\begin{array}{ll}\text { 1. } & \text { Menggunakan } \\
\text { kaidah bahasa yang } \\
\text { baik dan benar } \\
\text { sesuai ejaan yang } \\
\text { disempurnakan }\end{array}$ & 3.5 & SV & 87.5 \\
\hline & $\begin{array}{l}\text { Bahasa yang } \\
\text { digunakan bersifat } \\
\text { komunikatif }\end{array}$ & 3.5 & SV & 87.5 \\
\hline & $\begin{array}{ll}\text { 3. } & \begin{array}{l}\text { Struktur kalimat } \\
\text { yang digunakan } \\
\text { tepat }\end{array} \\
\end{array}$ & 3.5 & SV & 87.5 \\
\hline
\end{tabular}

Hasil validasi RPP oleh validator pada aspek format yang meliputi kelengkapan rumusan identitas, pembagian materi sesuai alokasi waktu, sistem penomoran, pengaturan ruang/tata letak, serta kesesuaian jenis dan ukuran huruf, dengan skor ratarata hasil validasi 100 (Sangat Valid). Hal ini karena RPP yang dikembangkan sesuai kurikulum 2013 melalui proses revisi untuk mendapatkan RPP yang layak. Hasil penilaian aspek isi dengan komponen penulisan Kompetensi Inti dan Kompetensi Dasar juga memperoleh rata-rata skor 100 dengan kriteria Sangat Valid, hal ini karena Kompetensi Inti dan Kompetensi Dasar pada RPP hanya menyalin dari silabus. Hasil penilaian pada komponen kelengkapan menuliskan indikator dan tujuan pembelajaran memperoleh skor rata-rata 87,5 dengan kriteria sangat valid karena komponen pada RPP yang dikembangkan sesuai dengan komponen penyusunan RPP menurut Permendikbud nomor 103 tahun 2015. Aspek ketepatan penjabaran KD ke dalam indikator mendapat penilaian rata-rata skor terendah namun masih dalam kategori valid, hal ini karena tata urutan penomoran dan penjabaran pada indikator belum sesuai dengan KD.

Hasil penilaian pada komponen kesesuaian dengan urutan materi memperoleh skor rata-rata 87,5 dengan kriteria sangat valid karena pembelajaran model inkuiri terbimbing untuk meningkatkan keterampilan proses sains sesuai jika diterapkan pada materi asam, basa, dan garam. Hasil penilaian pada komponen kegiatan guru dan kegiatan siswa dirumuskan secara jelas dan operasional mendapat kategori sangat valid dengan skor rata-rata 87,5 karena pengembangan perangkat pembelajaran dalam penelitian ini menggunakan model inkuiri terbimbing, dimana model ini mengubah pembelajaran dari teacher center menjadi student center. Hal ini sesuai dengan Inkuiri menurut Sanjaya dalam Nasution (2014), yang mengemukakan bahwa 
pembelajran inkuiri merupakan salah satu model pembelajaran yang menitikberatkan pada aktivitas siswa dalam pembelajaran.

Hasil penilaian RPP oleh validator pada aspek bahasa memperoleh rata-rata skor 87,5 dengan kriteria sangat valid dan sedikit revisi dalam hal penulisan. Peneliti melakukan revisi perangkat sesuai dengan saran dari validator sehingga perangkat tersebut dapat membantu dalam proses pembelajaran dan siswa dengan mudah memahaminya.

\section{Validasi Lembar Kegiatan Siswa}

Tabel 4.3 Hasil validasi penilaian kelayakan lembar kegiatan siswa (LKS)

\begin{tabular}{|l|l|c|l|l|}
\hline N & Aspek yang Dinilai & $\begin{array}{c}\text { Rer } \\
\text { ata } \\
\text { sko }\end{array}$ & K & a (\%) \\
r. & r & & \\
\hline & & & \\
\hline
\end{tabular}

I. FORMAT

\begin{tabular}{|c|l|c|c|c|}
\hline 1. & $\begin{array}{l}\text { Petunjuk } \\
\text { dinyatakan } \\
\text { dengan jelas }\end{array}$ & 3.5 & SV & 87.5 \\
\hline 2. & $\begin{array}{l}\text { Memilki } \\
\text { pengaturan } \\
\text { ruang/tata letak, } \\
\text { penomoran jelas, } \\
\text { jenis dan ukuran } \\
\text { huruf sesuai serta } \\
\text { konsistensi. }\end{array}$ & 3.5 & SV & 87.5 \\
\hline
\end{tabular}

II. ISI

\begin{tabular}{|c|l|c|c|c|}
\hline 1. & $\begin{array}{l}\text { Mencatumkan } \\
\text { tujuan } \\
\text { pembelajaran }\end{array}$ & 4 & SV & 100 \\
\hline 2. & $\begin{array}{l}\text { Kesesuaian materi } \\
\text { menggunakan } \\
\text { model inkuiri } \\
\text { terbimbing }\end{array}$ & 3 & $\mathrm{~V}$ & 75 \\
\hline
\end{tabular}

3. Memuat

keterampilan

proses sains yang

meliputi:

\begin{tabular}{|c|c|c|c|c|}
\hline & a. $\begin{array}{l}\text { Rumusan } \\
\text { masalah }\end{array}$ & 3 & $\mathrm{~V}$ & 75 \\
\hline & b. Hipotesis & 3 & $\mathrm{~V}$ & 75 \\
\hline & $\begin{array}{l}\text { c. } \\
\text { Variabel- } \\
\text { variabel } \\
\text { penelitian }\end{array}$ & 3 & $\mathrm{~V}$ & 75 \\
\hline & $\begin{array}{ll}\text { d. } & \begin{array}{l}\text { Definisi } \\
\text { operasional } \\
\text { variabel }\end{array} \\
\end{array}$ & 3 & $\mathrm{~V}$ & 75 \\
\hline & $\begin{array}{l}\text { e. Langkah- } \\
\text { langkah } \\
\text { kegiatan } \\
\text { percobaan }\end{array}$ & 3 & $\mathrm{~V}$ & 75 \\
\hline & $\begin{array}{ll}\text { f. } & \text { Hasil } \\
\text { pengamatan }\end{array}$ & 3 & $\mathrm{~V}$ & 75 \\
\hline & g. Analisis data & 3 & $\mathrm{~V}$ & 75 \\
\hline & h. Kesimpulan & 3 & $\mathrm{~V}$ & 75 \\
\hline 4. & student centered & 4 & & \\
\hline
\end{tabular}

\begin{tabular}{|l|l|l|c|c|c|}
\hline $\begin{array}{l}\text { N } \\
\text { o. }\end{array}$ & \multicolumn{2}{|l|}{ Aspek yang Dinilai } & $\begin{array}{c}\text { Rer } \\
\text { ata } \\
\text { sko } \\
\text { r }\end{array}$ & K & $\begin{array}{c}\text { Rerat } \\
\text { a (\%) }\end{array}$ \\
\hline & 5. & $\begin{array}{l}\text { Kesesuaian } \\
\text { pertanyaan } \\
\text { dengan tujuan } \\
\text { pembelajaran di } \\
\text { LKS dan RPP }\end{array}$ & 3 & SV & 100 \\
\hline 6. & $\begin{array}{l}\text { Prosedur kerja } \\
\text { dikaitkan dengan } \\
\text { kehidupan nyata }\end{array}$ & 3 & V & 75 \\
\hline $\begin{array}{l}\text { II } \\
\text { I. }\end{array}$ & BAHASA & $\begin{array}{l}\text { Menggunakan } \\
\text { kalimat } \\
\text { sederhana, jelas } \\
\text { dan mudah } \\
\text { dipahami serta } \\
\text { bahasa yang } \\
\text { digunakan bersifat } \\
\text { lugas dan } \\
\text { komunikatif }\end{array}$ & 3.5 & SV & 87.5 \\
\hline 2. & $\begin{array}{l}\text { Kesesuaian } \\
\text { kalimat dengan } \\
\text { taraf berpikir dan } \\
\text { perkembangan } \\
\text { siswa }\end{array}$ & 3.5 & SV & 87.5 \\
\hline
\end{tabular}

Hasil penilaian LKS oleh validator aspek format yang meliputi komponen petunjuk dan materi LKS sesuai dengan tujuan pembelajaran di RPP memperoleh skor rata-rata 87,5 dengan kategori sangat valid. Hal ini karena ditinjau dari aspek materi dan tujuan pembelajaran, LKS ini telah memuat materi dan tujuan pembelajaran sesuai RPP yang telah disusun dengan mempertimbangkan taraf berpikir siswa SMP. Aspek daya tarik, pengaturan ruang/tata letak, penomoran jelas, jenis dan ukuran huruf LKS juga memiliki kriteria sangat valid dengan skor rata-rata 87,5 karena ditinjau dari font style, font size, dan ukuran huruf lembar kerja siswa yang dikembangkan sudah mengikuti aturan karya tulis (tesis).

Aspek kevalidan isi mendapat skor rata-rata 75 dengan kriteria valid. Ditinjau dari kevalidan isi LKS model inkuiri terbimbing yang bertujuan untuk melatihkan keterampilan proses sains siswa, LKS ini dengan jelas memberikan keterangan mengenai keterampilan-keterampilan proses sains pada setiap tahapan langkah kegiatan siswa. Aspek kevalidan bahasa memperoleh skor rata-rata 87,5 dengan kategori sangat valid, karena LKS menggunakan kalimat sederhana, jelas dan mudah dipahami serta menggunakan bahasa yang bersifat lugas dan komunikatif. Aspek kesesuaian kalimat dengan taraf berpikir dan perkembangan siswa memperoleh skor rata-rata 87.5 


\section{Validasi Tes Keterampilan Proses Sains}

Tabel 4.5 Hasil validasi tes keterampilan proses sains siswa

\begin{tabular}{|c|c|c|c|c|c|c|c|c|}
\hline \multirow{3}{*}{$\begin{array}{l}\text { No. } \\
\text { Butir } \\
\text { Soal }\end{array}$} & \multicolumn{8}{|c|}{ Aspek yang dinilai } \\
\hline & \multicolumn{5}{|c|}{ Pretest } & \multicolumn{3}{|c|}{ Postest } \\
\hline & isi & $\begin{array}{l}\text { bah } \\
\text { asa }\end{array}$ & $\begin{array}{c}\text { Sko } \\
\mathbf{r} \\
(\%)\end{array}$ & $\mathbf{K}$ & isi & $\begin{array}{c}\text { bah } \\
\text { asa }\end{array}$ & $\begin{array}{c}\text { Sko } \\
\text { r } \\
(\%)\end{array}$ & $\mathbf{K}$ \\
\hline 1. MM & 3 & 3 & 75 & V & 3.5 & 3.5 & 87.5 & $\begin{array}{l}\mathrm{S} \\
\mathrm{V}\end{array}$ \\
\hline 2. $\mathrm{MH}$ & 3 & 3.5 & 81.3 & $\begin{array}{l}\mathrm{S} \\
\mathrm{V}\end{array}$ & 3.5 & 4 & 95 & $\begin{array}{l}\mathrm{S} \\
\mathrm{V}\end{array}$ \\
\hline 3. MV & 3 & 3.5 & 81.3 & $\begin{array}{l}\mathrm{S} \\
\mathrm{V}\end{array}$ & 3.5 & 4 & 95 & $\begin{array}{l}\mathrm{S} \\
\mathrm{V}\end{array}$ \\
\hline 4. $\begin{array}{l}\mathrm{DV} \\
\mathrm{O}\end{array}$ & 3 & 3.5 & 81.3 & $\begin{array}{l}\mathrm{S} \\
\mathrm{V}\end{array}$ & 3.5 & 4 & 95 & $\begin{array}{l}\mathrm{S} \\
\mathrm{V}\end{array}$ \\
\hline 5. $\begin{array}{l}M \\
D\end{array}$ & 3.5 & 3.5 & 87.5 & $\begin{array}{l}\mathrm{S} \\
\mathrm{V}\end{array}$ & 4 & 4 & 100 & $\begin{array}{l}\mathrm{S} \\
\mathrm{V}\end{array}$ \\
\hline 6. $\mathrm{AD}$ & 3 & 3.5 & 81.3 & $\begin{array}{l}\mathrm{S} \\
\mathrm{V}\end{array}$ & 3 & 4 & 87.5 & $\begin{array}{l}\mathrm{S} \\
\mathrm{V}\end{array}$ \\
\hline 7. $\begin{array}{l}\mathrm{M} \\
\mathrm{K}\end{array}$ & 3 & 3.5 & 81.3 & $\begin{array}{l}\mathrm{S} \\
\mathrm{V}\end{array}$ & 3 & 4 & 87.5 & $\begin{array}{l}\mathrm{S} \\
\mathrm{V}\end{array}$ \\
\hline
\end{tabular}

Keterangan: $\mathrm{K}$ :Kriteria SV : Sangat Valid V :Valid MM : Merumuskan Masalah DOV : Defenisi Operasional Variabel MH : Merumuskan Hipotesis MD : mengumpulkan Data MV : Menentukan Variabel

Tes keterampilan proses sains merupakan evaluasi yang dikembangkan oleh peneliti untuk mengukur pencapaian hasil belajar siswa berupa keterampilan proses sains yang meliputi; merumuskan masalah, merumuskan hipotesis, menentukan variabel, mendefinisikan operasional variabel, melakukan percobaan, menganalisis data, dan merumuskan kesimpulan. Tes keterampilan proses sains ini dikembangkan dalam bentuk soal uraian berdasarkan indikator yang telah dirumuskan sebelumnya.

Hasil validasi tes keterampilan proses sains yang dilakukan oleh validator menunjukkan bahwa 7 butir soal pretest maupun postest dinyatakan valid dengan revisi. Hasil validasi tes keterampilan proses sains soal pretest nomor 1 memperoleh skor rata-rata 75 karena gambar pada fenomena kurang jelas dan tanpa keterangan, sedangkan untuk soal nomor 2 sampai nomor 7 memperoleh skor rata-rata 81,3 dan dinyatakan sangat valid dengan revisi. Hasil penilaian pada soal postest memperoleh rata-rata skor 87,5 sampai 100 dengan kriteria sangat valid dan dapat digunakan tanpa revisi.

Berdasarkan hal-hal yang telah diuraikan di atas menunjukkan bahwa perangkat pembelajaran yang dikembangkan memiliki kategori sangat valid, sehingga dapat digunakan dalam pembelajaran IPA model inkuiri terbimbing yang ditunjang media PhET untuk melatihkan keterampilan proses sains kepada siswa. $\mathrm{AD}$ : Analisis Data MK : Merumuskan Kesimpulan

\section{B. Hasil Uji Coba Perangkat \\ 1. Keterlaksanaan RPP}

Tabel 4.7 Keterlaksanaan RPP pada uji coba II di kelas VIIa

\begin{tabular}{|c|c|c|c|c|c|c|c|}
\hline \multirow{2}{*}{$\begin{array}{l}\mathbf{N} \\
\text { o. }\end{array}$} & \multirow{2}{*}{$\begin{array}{l}\text { Aspek yang } \\
\text { diamati }\end{array}$} & \multicolumn{2}{|c|}{ TM 1} & \multicolumn{2}{|c|}{ TM 2} & \multicolumn{2}{|c|}{ TM 3} \\
\hline & & $\begin{array}{c}\mathbf{R} \\
(\%)\end{array}$ & $\mathbf{K}$ & $\begin{array}{l}\mathbf{R} \\
\%\end{array}$ & $\mathbf{K}$ & $\underset{(\%)}{R}$ & $\mathbf{K}$ \\
\hline
\end{tabular}

\section{AWAL}

\begin{tabular}{|c|c|c|c|c|c|c|c|}
\hline & $\begin{array}{l}\text { Memberi } \\
\text { salam }\end{array}$ & 100 & $\begin{array}{l}\mathrm{S} \\
\mathrm{B}\end{array}$ & 100 & $\begin{array}{l}\mathrm{S} \\
\mathrm{B}\end{array}$ & 100 & $\begin{array}{l}\mathrm{S} \\
\mathrm{B}\end{array}$ \\
\hline 2. & $\begin{array}{l}\text { Memulai } \\
\text { PBM } \\
\text { dengan } \\
\text { berdoa. }\end{array}$ & 100 & $\begin{array}{l}S \\
B\end{array}$ & 100 & $\begin{array}{l}S \\
B\end{array}$ & 100 & $\begin{array}{l}\mathrm{S} \\
\mathrm{B}\end{array}$ \\
\hline & $\begin{array}{l}\text { Memotivasi } \\
\text { siswa }\end{array}$ & 87.5 & $\begin{array}{l}\mathrm{S} \\
\mathrm{B}\end{array}$ & 100 & $\begin{array}{l}\mathrm{S} \\
\mathrm{B}\end{array}$ & 100 & $\begin{array}{l}\mathrm{S} \\
\mathrm{B}\end{array}$ \\
\hline & $\begin{array}{l}\text { Menyampai } \\
\text { kan tujuan } \\
\text { pembelajara } \\
\text { n. }\end{array}$ & 100 & $\begin{array}{l}S \\
B\end{array}$ & 100 & $\begin{array}{l}\mathrm{S} \\
\mathrm{B}\end{array}$ & 100 & $\begin{array}{l}\mathrm{S} \\
\mathrm{B}\end{array}$ \\
\hline 5. & $\begin{array}{l}\text { Membagika } \\
\text { n kelompok. }\end{array}$ & 100 & $\begin{array}{l}\mathrm{S} \\
\mathrm{B}\end{array}$ & 100 & $\begin{array}{l}\mathrm{S} \\
\mathrm{B}\end{array}$ & 100 & $\begin{array}{l}\text { S } \\
\text { B }\end{array}$ \\
\hline & $\begin{array}{l}\text { Membagika } \\
\text { n LKS. }\end{array}$ & 100 & $\begin{array}{l}\mathrm{S} \\
\mathrm{B}\end{array}$ & 100 & $\begin{array}{l}\mathrm{S} \\
\mathrm{B}\end{array}$ & 100 & $\begin{array}{l}S \\
B\end{array}$ \\
\hline
\end{tabular}

II. KEGIATAN

INTI

\begin{tabular}{|c|c|c|c|c|c|c|}
\hline 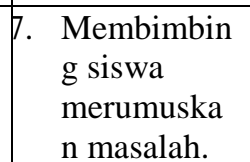 & 87.5 & $\begin{array}{l}\mathrm{S} \\
\mathrm{B}\end{array}$ & 100 & $\begin{array}{l}\mathrm{S} \\
\mathrm{B}\end{array}$ & 100 & $\begin{array}{l}\mathrm{S} \\
\mathrm{B}\end{array}$ \\
\hline 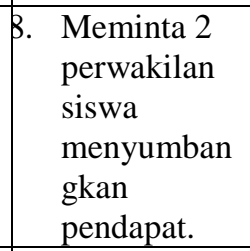 & 87.5 & $\begin{array}{l}\mathrm{S} \\
\mathrm{B}\end{array}$ & 100 & $\begin{array}{l}\mathrm{S} \\
\mathrm{B}\end{array}$ & 100 & $\begin{array}{l}\mathrm{S} \\
\mathrm{B}\end{array}$ \\
\hline $\begin{array}{l}\text { Merumuska } \\
\text { n hipotesis. }\end{array}$ & 87.5 & $\begin{array}{l}\mathrm{S} \\
\mathrm{B}\end{array}$ & 100 & $\begin{array}{l}\mathrm{S} \\
\mathrm{B}\end{array}$ & 100 & $\begin{array}{l}\mathrm{S} \\
\mathrm{B}\end{array}$ \\
\hline $\begin{array}{l}\text { 10. Menyumban } \\
\text { gkan } \\
\text { pendapat. }\end{array}$ & 87.5 & $\begin{array}{l}\mathrm{S} \\
\mathrm{B}\end{array}$ & 100 & $\begin{array}{l}\mathrm{S} \\
\mathrm{B}\end{array}$ & 100 & $\begin{array}{l}\mathrm{S} \\
\mathrm{B}\end{array}$ \\
\hline $\begin{array}{l}\text { 11. Mengidentif } \\
\text { ikasi } \\
\text { variabel } \\
\text { manipulasi, } \\
\text { variabel } \\
\text { kontrol, dan } \\
\text { variabel } \\
\text { respon. }\end{array}$ & 87.5 & $\begin{array}{l}\mathrm{S} \\
\mathrm{B}\end{array}$ & 100 & $\begin{array}{l}\mathrm{S} \\
\mathrm{B}\end{array}$ & 100 & $\begin{array}{l}\mathrm{S} \\
\mathrm{B}\end{array}$ \\
\hline \begin{tabular}{|l} 
12. Mendefinisi \\
kan \\
operasional \\
variabel.
\end{tabular} & 100 & $\begin{array}{l}\mathrm{S} \\
\mathrm{B}\end{array}$ & 87,5 & $\begin{array}{l}\mathrm{S} \\
\mathrm{B}\end{array}$ & 100 & $\begin{array}{l}\mathrm{S} \\
\mathrm{B}\end{array}$ \\
\hline $\begin{array}{l}\text { 13. Merencanak } \\
\text { an } \\
\text { pengamatan }\end{array}$ & 87.5 & $\begin{array}{l}\mathrm{S} \\
\mathrm{B}\end{array}$ & 100 & $\begin{array}{l}\mathrm{S} \\
\mathrm{B}\end{array}$ & 100 & $\begin{array}{l}\mathrm{S} \\
\mathrm{B}\end{array}$ \\
\hline
\end{tabular}

Pengembangan Perangkat Pembelajaran IPA Model 


\begin{tabular}{|c|c|c|c|c|c|c|c|}
\hline \multirow[b]{2}{*}{$\begin{array}{l}\mathbf{N} \\
\mathbf{o .}\end{array}$} & \multirow[b]{2}{*}{$\begin{array}{l}\text { Aspek yang } \\
\text { diamati }\end{array}$} & \multicolumn{2}{|c|}{ TM 1} & \multicolumn{2}{|c|}{ TM 2} & \multicolumn{2}{|c|}{ TM 3} \\
\hline & & $\begin{array}{c}\mathbf{R} \\
(\%)\end{array}$ & $\mathbf{K}$ & $\begin{array}{l}\mathbf{R} \\
\%\end{array}$ & $\mathbf{K}$ & $\begin{array}{c}\mathbf{R} \\
(\%)\end{array}$ & $\mathbf{K}$ \\
\hline & $\begin{array}{l}\text { 14. Siswa } \\
\text { bertanya. }\end{array}$ & 87.5 & $\begin{array}{l}\mathrm{S} \\
\mathrm{B}\end{array}$ & 100 & \begin{tabular}{|l|}
$\mathrm{S}$ \\
$\mathrm{B}$ \\
\end{tabular} & 100 & $\begin{array}{l}\mathrm{S} \\
\mathrm{B} \\
\end{array}$ \\
\hline & $\begin{array}{l}\text { 15. Siswa } \\
\text { melakukan } \\
\text { percobaan. }\end{array}$ & 87.5 & $\begin{array}{l}\mathrm{S} \\
\mathrm{B}\end{array}$ & 100 & $\begin{array}{l}\mathrm{S} \\
\mathrm{B}\end{array}$ & 100 & $\begin{array}{l}\text { S } \\
\text { B }\end{array}$ \\
\hline & $\begin{array}{l}\text { 16. Melakukan } \\
\text { pengamatan. }\end{array}$ & 87.5 & $\begin{array}{l}\mathrm{S} \\
\mathrm{B} \\
\end{array}$ & 100 & \begin{tabular}{|l|}
$\mathrm{S}$ \\
$\mathrm{B}$ \\
\end{tabular} & 100 & \begin{tabular}{|l|}
$\mathrm{S}$ \\
$\mathrm{B}$ \\
\end{tabular} \\
\hline & $\begin{array}{l}\text { 17. Menganalisi } \\
\text { s data hasil } \\
\text { percobaan. }\end{array}$ & 100 & $\begin{array}{l}\mathrm{S} \\
\mathrm{B}\end{array}$ & 100 & \begin{tabular}{|l|} 
S \\
B
\end{tabular} & 100 & $\begin{array}{l}\mathrm{S} \\
\mathrm{B}\end{array}$ \\
\hline & $\begin{array}{l}\text { 18. Mempresent } \\
\text { asikan hasil } \\
\text { percobaan. }\end{array}$ & 87.5 & $\begin{array}{l}\mathrm{S} \\
\mathrm{B} \\
\end{array}$ & 87.5 & $\begin{array}{l}\mathrm{S} \\
\mathrm{B}\end{array}$ & 100 & $\begin{array}{l}\mathrm{S} \\
\mathrm{B}\end{array}$ \\
\hline & 19. N & 7.5 & $\begin{array}{l}\mathrm{S} \\
\mathrm{B}\end{array}$ & 87.5 & \begin{tabular}{|l|}
$\mathrm{S}$ \\
$\mathrm{B}$ \\
\end{tabular} & 100 & $\begin{array}{l}\mathrm{S} \\
\mathrm{B} \\
\end{array}$ \\
\hline III & \begin{tabular}{|c|} 
KEGIATAN \\
PENUTUP
\end{tabular} & & & & & & \\
\hline & $\begin{array}{l}\text { 20. merumuska } \\
\mathrm{n} \\
\text { kesimpulan. }\end{array}$ & 87.5 & $\begin{array}{l}\mathrm{S} \\
\mathrm{B}\end{array}$ & 100 & $\mid \begin{array}{l}\mathrm{S} \\
\mathrm{B}\end{array}$ & 100 & $\begin{array}{l}\mathrm{S} \\
\mathrm{B}\end{array}$ \\
\hline & $\begin{array}{l}\text { 21. Siswa } \\
\text { meneliti } \\
\text { kesimpulan } \\
\text { benar-benar } \\
\text { menjawab } \\
\text { hipotesis. }\end{array}$ & 87.5 & $\begin{array}{l}\mathrm{S} \\
\mathrm{B}\end{array}$ & 87.5 & $\begin{array}{l}\mathrm{S} \\
\mathrm{B}\end{array}$ & 100 & $\begin{array}{l}\text { S } \\
\text { B }\end{array}$ \\
\hline & $\begin{array}{l}\text { 22. Melakukan } \\
\text { refleksi }\end{array}$ & 87.5 & $\begin{array}{l}\mathrm{S} \\
\mathrm{B}\end{array}$ & 100 & \begin{tabular}{|l|}
$\mathrm{S}$ \\
$\mathrm{B}$ \\
\end{tabular} & 100 & $\begin{array}{l}\mathrm{S} \\
\mathrm{B}\end{array}$ \\
\hline & \begin{tabular}{|l} 
23. Siswa \\
diberikan \\
tugas \\
rumah.
\end{tabular} & 87.5 & $\begin{array}{l}\mathrm{S} \\
\mathrm{B}\end{array}$ & 87.5 & $\begin{array}{l}\mathrm{S} \\
\mathrm{B}\end{array}$ & 100 & $\begin{array}{l}\mathrm{S} \\
\mathrm{B}\end{array}$ \\
\hline & 24. Menutup & 100 & $\begin{array}{l}\mathrm{S} \\
\mathrm{B}\end{array}$ & 100 & \begin{tabular}{|l|}
$\mathrm{S}$ \\
$\mathrm{B}$ \\
\end{tabular} & 100 & $\begin{array}{l}\mathrm{S} \\
\mathrm{B}\end{array}$ \\
\hline IV & \begin{tabular}{|c|} 
PENGELOLA \\
HAN \\
WAKTU \\
\end{tabular} & & & & & & \\
\hline & $\begin{array}{l}\text { 25. Ketepatan } \\
\text { waktu }\end{array}$ & 87.5 & $\begin{array}{l}\mathrm{S} \\
\mathrm{B}\end{array}$ & 87.5 & \begin{tabular}{|l|}
$\mathrm{S}$ \\
$\mathrm{B}$ \\
\end{tabular} & 100 & $\begin{array}{l}\mathrm{S} \\
\mathrm{B}\end{array}$ \\
\hline v. & $\begin{array}{r}\text { SUASANA } \\
\text { KELAS }\end{array}$ & & & & & & \\
\hline & $\begin{array}{l}\text { 26. Siswa } \\
\text { antusias }\end{array}$ & 100 & $\begin{array}{l}\mathrm{S} \\
\mathrm{B}\end{array}$ & 87.5 & \begin{tabular}{|l|}
$\mathrm{S}$ \\
$\mathrm{B}$
\end{tabular} & 100 & $\begin{array}{l}\mathrm{S} \\
\mathrm{B}\end{array}$ \\
\hline & $\begin{array}{r}27 . \text { Guru } \\
\text { antusia }\end{array}$ & 100 & $\begin{array}{l}\mathrm{S} \\
\mathrm{B} \\
\end{array}$ & 100 & \begin{tabular}{|l|}
$\mathrm{S}$ \\
$\mathrm{B}$ \\
\end{tabular} & 100 & $\begin{array}{l}\mathrm{S} \\
\mathrm{B}\end{array}$ \\
\hline
\end{tabular}

K : Kriteria SB : Sangat Baik B : Baik R: Rata-rata TB : Tidak Baik KB : Kurang Baik TM: Tatap Muka

Hasil pengamatan terhadap keterlaksanaan RPP yang disajikan pada Tabel 4.7, rata-rata penilaian dari dua orang pengamat adalah $87,5 \%$ dan $100 \%$ dengan persentase reliabilitas sebesar $98 \%$. Berdasarkan data tersebut dapat dinyatakan bahwa instrumen yang digunakan reliabel. Kegiatan awal dalam pembelajaran ini yaitu guru memulai pembelajaran dengan memberi salam dan mengajak siswa berdoa untuk menanamkan kesadaran dan rasa syukur atas kebesaran Tuhan. Keterlaksanaan RPP pada kegiatan ini memperoleh skor tertinggi dengan rata-rata penilaian dari dua pengamat adalah 100\% karena telah sesuai dengan Kompetensi Inti 1. Kegiatan selanjutnya memberi motivasi dan menyampaikan tujuan pembelajaran. Hasil penilaian tahap menyampaikan motivasi pada pertemuan pertama hingga pertemuan terakhir mendapat nilai yang sangat baik (Ratumanan \& Laurens, 2011) dengan skor rata-rata 95,8. Hal ini karena pada kegiatan memotivasi siswa disajikan sebuah fenomena tentang asam, basa, dan garam yang dekat dengan kehidupan siswa sehari-hari sehingga dengan kegiatan tersebut siswa dapat termotivasi dan antusias mengikuti pembelajaran.

Keterlaksanaan RPP pada kegiatan inti pembelajaran IPA dengan model inkuiri terbimbing ditunjang media PhET yang meliputi merumuskan masalah, membuat hipotesis, menentukan variabel, mendefinisikan operasional variabel, melakukan percobaan, menganalisis data, dan membuat kesimpulan, secara keseluruhan memperoleh nilai ratarata dari 87,5 sampai 100 dari dua orang pengamat, dengan kriteria sangat baik (Ratumanan \& Laurens, 2011).

Kegiatan penutup yaitu tahap siswa melakukan refleksi dengan dibantu guru, pemberian tugas, serta penutupan belajar dengan berdoa memperoleh nilai yang sangat baik karena kegiatan ini sudah rutin dilakukan siswa. Aspek pengelolahan waktu pada pertemuan pertama dan pertemuan kedua lebih rendah dari pertemuan ketiga, hal ini disebabkan siswa belum terbiasa dengan pembelajaran menggunakan IPA model inkuiri terbimbing dan siswa terlalu asyik dalam percobaan sehingga tidak memperhatikan alokasi waktu yang diberikan walaupun guru sudah mengingatkan.

2. Hasil Pengamatan Aktivitas Siswa

Tabel 4.8 Aktivitas Siswa saat proses pembelajaran

\begin{tabular}{|l|l|l|l|l|l|}
\hline N & $\begin{array}{l}\text { Aspek yang } \\
\text { o. }\end{array}$ & \multicolumn{2}{|l|}{ Frekuensi (\%) } & R \\
\cline { 2 - 5 } 1. & $\begin{array}{l}\text { Mendengarkan } \\
\text { dan } \\
\text { memperhatikan } \\
\text { penjelasan guru }\end{array}$ & 27 & 28 & 29 & 28 \\
\hline 2. & Membaca LKS & 27 & 27 & 27 & 27 \\
\hline 3. & $\begin{array}{l}\text { Mengajukan } \\
\text { pertanyaan }\end{array}$ & 35 & 34 & 34 & 34 \\
\hline 4. & $\begin{array}{l}\text { Melakukan } \\
\text { percobaan }\end{array}$ & 61 & 62 & 60 & 61 \\
\hline 5. & Mengerjakan LKS & 64 & 63 & 62 & 63 \\
\hline 6. & $\begin{array}{l}\text { Mempresentasika } \\
\text { n hasil percobaan }\end{array}$ & 10 & 10 & 10 & 10 \\
\hline 7. & $\begin{array}{l}\text { Mendengarkan } \\
\text { presentasi }\end{array}$ & 26 & 26 & 28 & 26 \\
\hline 8. & $\begin{array}{l}\text { Memperlihatkan } \\
\text { perilaku tidak } \\
\text { relevan }\end{array}$ & 1 & 1 & 0 & 1 \\
\hline
\end{tabular}


Berdasarkan data pada Tabel 4.8 didapatkkan persentase tertinggi pertemuan 1,2 dan 3 yakni aktivitas melakukan pengamatan/ percobaan dengan rata-rata persentase $61 \%$ dan mengerjakan LKS/ menyelesaiakan tugas belajar sebesar $63 \%$ dari total keseluruhan aktivitas, sedangkan persentase terendah pertemuan 1, 2, dan 3 yakni pada aktivitas memperlihatkan perilaku yang tidak relevan saat pembelajaran.

\section{Analisis Tes Keterampilan Proses Sains}

Tabel 4.9 Hasil Pre Test dan Post Test tiap Siswa dan skor $N$-Gain

\begin{tabular}{|c|c|c|c|c|c|c|c|c|}
\hline \multirow{2}{*}{$\begin{array}{l}\text { Inisi } \\
\text { al } \\
\text { Sisw } \\
\text { a } \\
\end{array}$} & \multicolumn{3}{|c|}{ Pre Test } & \multicolumn{3}{|c|}{ Post Test } & \multirow[b]{2}{*}{$\begin{array}{l}N- \\
\text { Gai } \\
n\end{array}$} & \multirow[b]{2}{*}{$\begin{array}{l}\text { Kriteri } \\
\text { a }\end{array}$} \\
\hline & $\begin{array}{l}\text { Nil } \\
\text { ai }\end{array}$ & $\mathbf{P}$ & $\begin{array}{l}\mathrm{Kt} \\
\mathrm{S}\end{array}$ & $\begin{array}{l}\text { Nil } \\
\text { ai }\end{array}$ & $\mathbf{P}$ & $\begin{array}{l}\text { Kt } \\
s\end{array}$ & & \\
\hline S1 & 10 & $\mathrm{D}$ & $\mathrm{TT}$ & 80 & $B$ & $\mathrm{~T}$ & $\begin{array}{l}0.7 \\
8\end{array}$ & Tinggi \\
\hline S2 & 17 & $\mathrm{D}$ & $\mathrm{TT}$ & 80 & $B$ & $\mathrm{~T}$ & $\begin{array}{l}0.7 \\
6\end{array}$ & Tinggi \\
\hline S3 & 17 & $\mathrm{D}$ & $\mathrm{TT}$ & 83 & $B$ & $\mathrm{~T}$ & $\begin{array}{l}0.8 \\
0\end{array}$ & Tinggi \\
\hline S4 & 13 & $\mathrm{D}$ & $\mathrm{TT}$ & 80 & $\begin{array}{l}\text { B } \\
+\end{array}$ & $\mathrm{T}$ & $\begin{array}{l}0.7 \\
7\end{array}$ & Tinggi \\
\hline S5 & 10 & $\mathrm{D}$ & $\mathrm{TT}$ & 80 & $B$ & $\mathrm{~T}$ & $\begin{array}{l}0.7 \\
8\end{array}$ & Tinggi \\
\hline S6 & 17 & $\mathrm{D}$ & $\mathrm{TT}$ & 87 & A- & $\mathrm{T}$ & $\begin{array}{l}0.8 \\
4\end{array}$ & Tinggi \\
\hline S7 & 10 & $\mathrm{D}$ & $\mathrm{TT}$ & 83 & $B$ & $\mathrm{~T}$ & $\begin{array}{l}0.8 \\
1\end{array}$ & Tinggi \\
\hline S8 & 13 & $\mathrm{D}$ & $\mathrm{TT}$ & 90 & A- & $\mathrm{T}$ & $\begin{array}{l}0.8 \\
9\end{array}$ & Tinggi \\
\hline S9 & 17 & $D$ & TT & 83 & $B$ & $\mathrm{~T}$ & $\begin{array}{l}0.8 \\
0 \\
\end{array}$ & Tinggi \\
\hline S10 & 13 & $\mathrm{D}$ & $\mathrm{TT}$ & 90 & $B$ & $\mathrm{~T}$ & $\begin{array}{l}0.8 \\
9 \\
\end{array}$ & Tinggi \\
\hline S11 & 13 & $\mathrm{D}$ & $\mathrm{TT}$ & 83 & $\begin{array}{l}B \\
+\end{array}$ & $\mathrm{T}$ & $\begin{array}{l}0.8 \\
0\end{array}$ & Tinggi \\
\hline S12 & 10 & $\mathrm{D}$ & $\mathrm{TT}$ & 83 & $B$ & $\mathrm{~T}$ & $\begin{array}{l}0.8 \\
1 \\
\end{array}$ & Tinggi \\
\hline S13 & 13 & $\mathrm{D}$ & TT & 87 & $\begin{array}{l}\text { B } \\
+ \\
\end{array}$ & $T$ & $\begin{array}{l}0.8 \\
5 \\
\end{array}$ & Tinggi \\
\hline S14 & 10 & $\mathrm{D}$ & TT & 80 & $B$ & $T$ & $\begin{array}{l}0.7 \\
8\end{array}$ & Tinggi \\
\hline S15 & 13 & D & TT & 83 & $B$ & $\mathrm{~T}$ & $\begin{array}{l}0.8 \\
0 \\
\end{array}$ & Tinggi \\
\hline S16 & 10 & $\mathrm{D}$ & TT & 83 & $B$ & $\mathrm{~T}$ & $\begin{array}{l}0.8 \\
1 \\
\end{array}$ & Tinggi \\
\hline S17 & 10 & $\mathrm{D}$ & $\mathrm{TT}$ & 87 & $\begin{array}{l}\text { B } \\
+\end{array}$ & $\mathrm{T}$ & $\begin{array}{l}0.8 \\
6\end{array}$ & Tinggi \\
\hline S18 & 13 & $\mathrm{D}$ & $\mathrm{TT}$ & 80 & $B$ & $T$ & $\begin{array}{l}0.7 \\
7 \\
\end{array}$ & Tinggi \\
\hline S19 & 10 & $\mathrm{D}$ & $\mathrm{TT}$ & 83 & $B$ & $T$ & $\begin{array}{l}0.8 \\
0 \\
\end{array}$ & Tinggi \\
\hline S20 & 10 & $\mathrm{D}$ & TT & 83 & $B$ & $T$ & $\begin{array}{l}0.8 \\
0\end{array}$ & Tinggi \\
\hline
\end{tabular}

Pengembangan Perangkat Pembelajaran IPA Model Inkuiri Terbimbing...........

\begin{tabular}{|l|l|l|l|l|l|l|l|l|}
\hline \multirow{2}{*}{$\begin{array}{l}\text { Inisi } \\
\text { al } \\
\begin{array}{l}\text { Sisw } \\
\text { a }\end{array}\end{array}$} & $\begin{array}{l}\text { Pil } \\
\text { ai }\end{array}$ & P & $\begin{array}{l}\text { Kt } \\
\text { s }\end{array}$ & $\begin{array}{l}\text { Nil } \\
\text { ai }\end{array}$ & P & $\begin{array}{l}\text { Kt } \\
\text { s }\end{array}$ & $\begin{array}{l}\text { Gai } \\
n\end{array}$ & $\begin{array}{l}\text { Kriteri } \\
\mathbf{a}\end{array}$ \\
\hline S21 & 13 & D & TT & 80 & B & T & $\begin{array}{l}0.7 \\
7\end{array}$ & Tinggi \\
\hline S22 & 10 & D & TT & 83 & B & T & $\begin{array}{l}0.8 \\
1\end{array}$ & Tinggi \\
\hline S23 & 17 & D & TT & 80 & B & T & $\begin{array}{l}0.7 \\
6\end{array}$ & Tinggi \\
\hline S24 & 17 & D & TT & 83 & B & T & $\begin{array}{l}0.8 \\
0\end{array}$ & Tinggi \\
\hline S25 & 10 & D & TT & 80 & B & T & $\begin{array}{l}0.7 \\
8\end{array}$ & Tinggi \\
\hline S26 & 13 & D & TT & 80 & B & T & $\begin{array}{l}0.7 \\
7\end{array}$ & Tinggi \\
\hline S27 & 10 & D & TT & 80 & B & T & $\begin{array}{l}0.7 \\
8\end{array}$ & Tinggi \\
\hline S28 & 10 & D & TT & 87 & $\begin{array}{l}\text { B } \\
+\end{array}$ & T & $\begin{array}{l}0.8 \\
6\end{array}$ & Tinggi \\
\hline S29 & 13 & D & TT & 83 & B & T & $\begin{array}{l}0.8 \\
0\end{array}$ & Tinggi \\
\hline S30 & 17 & D & TT & 80 & B & T & $\begin{array}{l}0.7 \\
6\end{array}$ & Tinggi \\
\hline & & & & & & $\begin{array}{l}0.8 \\
0\end{array}$ & Tinggi \\
\hline
\end{tabular}

Keterangan: Kts: Ketuntasan P: Predikat S: siswa TT: Tidak Tuntas T: Tuntas

Hasil tes keterampilan proses sains dalam uji coba II disajikan pada Tabel 4.9 menunjukkan bahwa pada tes awal (pretest) tidak ada siswa yang tuntas dengan nilai rata-rata 13 , rendahnya tes awal keterampilan proses sains siswa disebabkan siswa selama ini belum pernah diajarkan dan dilatihkan keterampilan proses sains sehingga soal keterampilan proses sains adalah hal baru bagi siswa.

Hasil tes akhir (postest) setelah menggunakan pembelajaran dengan model inkuiri terbimbing ditunjang media PhET seluruh siswa telah tuntas baik secara individu maupun klasikal, dengan nilai rata-rata 84. Berdasarkan tes awal sebelum siswa mengikuti kegiatan belajar mengajar dan tes akhir setelah mengikuti kegiatan belajar mengajar menggunakan pembelajaran model inkuiri terbimbing mengalami peningkatan rata-rata $70 \%$ untuk masing-masing siswa.

\section{Analisis Respon Siswa}

Rekapitulasi hasil respon 30 siswa terhadap kegiatan pembelajaran dan perangkat pembelajaran IPA model inkuiri terbimbing ditunjang media PhET untuk meningkatkan keterampilan proses sains disajikan pada Tabel 4.10 dan selengkapnya pada lampiran 5d halaman 257.

Persentase skor respon siswa terhadap komponen yang terlibat dalam kegiatan pembelajaran disajikan pada diagram Gambar 4.3 sebagai berikut: 


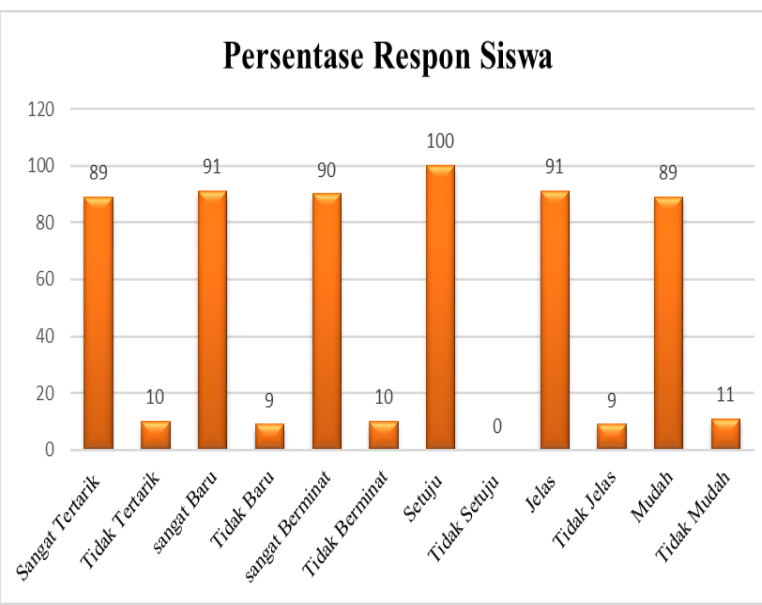

Gambar 4.3 Persentase Respon Siswa

Gambar 4.3 menunjukkan bahwa respon siswa terhadap ketertarikan, kebaruan, kemudahan serta kejelasan siswa dalam proses pembelajaran dan perangkat yang dikembangkan berkriteria baik dengan persentase respon $80 \%$ sampai $100 \%$.

\section{PENUTUP}

\section{A. Simpulan}

Berdasarkan hasil penelitian yang telah dilakukan, maka dapat disimpulkan bahwa perangkat pembelajaran IPA model inkuiri terbimbing ditunjang media PhET yang dikembangkan layak untuk digunakan dalam pembelajaran dan dapat meningkatkan keterampilan proses sains siswa. Hal ini dibuktikan dari: 1) validitas perangkat pembelajaran yang dikembangkan dengan kategori sangat valid, 2) keterlaksanaan RPP berkategori sangat baik dengan persentase reliabelitas $98 \%$, 3) aktivitas siswa tertinggi pada aktivitas melakukan percobaan dan mengerjakan LKS, 4) respon siswa terhadap perangkat dan pelaksanaan pembelajaran mencapai persentase di atas $80 \%$ dengan kriteria sangat kuat; dan 5) Peningkatan keterampilan proses sains dengan $\mathrm{N}$-gain 0,80 , kriteria tinggi.

\section{B. Saran}

1. Penelitian selanjutnya disarankan sebelum melakukan pembelajaran agar memberi penjelasan mengenai model inkuiri terbimbing (Guided inquiry) kapada siswa.

2. Keterampilan proses sains perlu dilatihkan secara berkelanjutan pada setiap pembelajaran IPA, sehingga dapat membiasakan siswa dengan berbagai jenis keterampilan proses sains.

\section{DAFTAR PUSTAKA}

Arends, R. (2008). Learning to Teach Buku Satu, Edisi Ketujuh. New York: Mc-Graw Hill

Arikunto, Suharsimi. (2010). Prosedur Penelitian Suatu Pendekatan Praktik. Jakarta: Rineka Cipta.
Badan Standar Nasional Pendidikan. (2006). Standar Isi untuk Satuan Pendidikan Dasar dan Menengah. Jakarta: BSNP.

Banerjee, A. (2010). “Teaching science using guided inquiry as the central theme: A professional development model for high school science teachers". Science Educator, 19(2), 1-9.

Chang, Raymond. (2003). Kimia Dasar: Konsepkonsep Inti. Jakarta: Erlangga.

Collette, A.T. dan Chiapetta, E.L. (1994). Science Instructions in The Middle and Scondary Schools. New York: Macmillan Publishing Company.

Dahar, Ratna W. (1988). Teori-teori belajar dan pembelajaran. Bandung: Erlangga.

Daryanto. (2013). Media Pembelajaran. Yogyakarta: Gava Media

Depdiknas. (2007). Model Silabus dan Rencana Pelaksanaan Pembelajaran. Jakarta: Depdiknas.

Devi, Kamila. (2011). Keterampilan Proses dalam Pembelajaran IPA. Jakarta: PPPTK IPA.

Dyah, Permata., dkk. (2014). "Uji Coba Pembelajaran IPA dengan LKS sebagai Penunjang Media Virtual PhET untuk Melatih Keterampilan Proses pada Materi Hukum Archimedes". Jurnal Pendidikan Sains e-Pensa. Volume 01 Nomor 02 Tahun 2013, 15-20.

Gulo, W. (2002). Strategi Belajar Mengajar. Jakarta: PT. Grasindo.

Ibrahim, Muslimin. (2010). Pengembangan Pembelajaran Berbasis Inkuiri, Modeling, dan Eksperimen. Makalah Seminar Yayasan Beasiswa Tunas Bangsa Surabaya.

Kemendikbud. (2013). Materi Pelatihan Guru Implementasi Kurikulum 2013 SMP/MTs IPA. Jakarta: Kementerian Pendidikan dan Kebudayaan.

Kuhlthau, C.C. Maniotes, L.K. and Caspari, A.K. (2012). Guided inquiry design. Libraries Unlimeted:Imprint ABC

Manku, G.S., 2001, Inorganic Chemistry, Tata Mc Graw-Hill Publishing Company Limited, New Delhi

National Research Council. (2000). Inquiry and The National Science Educational Students A Guide For Teaching and Learning. United States: National Academics Press.

Nur, M. (2011). Modul Keterampilan-keterampilan Proses Sains. Disadur dari Inquiry Skill Activity Book. Pusat Sains dan Matematika Sekolah: Universitas Negeri Surabaya.

Ratumanan, T. G., dan Laurens T. (2011). Penilaian hasil belajar pada tingkat satuan pendidikan edisi 2. Surabaya: Unesa University Press.

Riduwan. (2010). Skala Pengukuran Variabelvariabel Penelitian Bandung: Alfabeta.

Sanjaya, Wina. (2011). Strategi pembelajaran berorientasi standar proses pendidikan. Jakarta: Kencana Prenada Media. 
Slavin, R. E. (2011). Psikologi Pendidikan Teori dan Praktik Jilid 2. Jakarta: PT Indeks.

Sugiyono. (2014). Metode Penelitian Pendidikan Pendekatan Kuantitatif, Kualitatif, dan $R \& D$. Bandung: Alfabeta.

Sujana, Nana \& Ahmad Rivai. (2010). Media Pengajaran. Bandung: Sinar Baru Algesindo.

Vajoczki, S., Watt, S., Vine, M.M., dan Liao, X. (2011). "inquiry learning: Level, Dicipline, Class Size, What Matter?”. International Journal for The Scholarship of Teaching and Learning, Vol. 5 No. 1, pp 1-11 